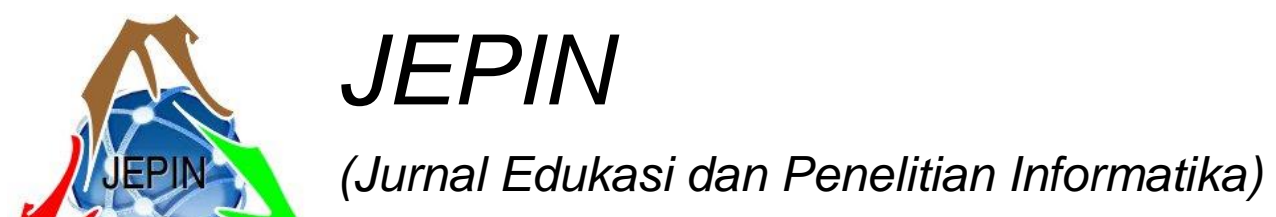

\title{
Rancangan Sistem Informasi Pengelolaan Audit Mutu Internal (AMI) Perguruan Tinggi
}

\author{
Eva Faja Ripanti ${ }^{\# 1}$, H. A. Oramahi*2 \\ \#Jurusan Informatika, Fakultas Teknik, Universitas Tanjungpura \\ Jl. Prof. Dr. H. Hadari Nawawi, Pontianak, Indonesia \\ levaripanti@untan.ac.id \\ *Pusat Penjaminan Mutu, Universitas Tanjungpura \\ Jl. Daya Nasional, Pontianak, Indonesia \\ ºramahi_stp@yahoo.com
}

\begin{abstract}
Abstrak - Tujuan penelitian adalah merancang sebuah sistem informasi untuk pengelolaan audit mutu internal (AMI) yang menjadi bagian dari siklus Sistem Penjaminan Mutu Internal (SPMI) Pendidikan Tinggi (Dikti), yaitu evaluasi pelaksanaan standar Dikti. AMI berperan dalam proses pemeriksaan pemenuhan Standar Dikti pada tahap pelaksanaan standar. Banyaknya proses dalam sistem AMI mulai dari mulai deskevaluation, visitasi, permintaan tindakan koreksi, dan dokumentasi. Ditambah lagi kegiatan AMI yang idealnya dilaksanakan setiap tahun untuk setiap program studi, dan jumlah auditor yang terbatas menuntut dibangunnya sebuah sistem informasi agar proses monitoring dan pengambilan keputusan dapat dilakukan dengan mudah, sehingga pengelolaan dapat berjalan efisien dan berkelanjutan. Sistem informasi diperlukan, sistem ini dikembangkan dengan pendekatan System Development Life Cycle (SDLC), dimana dalam proses pengembangannya terdapat empat tahapan besar yaitu perencanaan, analisis, perancangan, dan implementasi. Sistem AMI yang dirancang untuk dapat digunakan secara umum pada proses AMI di perguruan tinggi, terutama di Universitas Tanjungpura (Untan). Beberapa kendala yang dihadapi sebelum menggunakan sistem informasi, misalnya sulitnya mengetahui dengan cepat informasi terkait perbaikan mutu untuk setiap program studi secara periodik. Penelitian ini menghasilkan sebuah rancangan sistem informasi yang mengelola kebutuhan AMI secara terintegrasi mulai dari proses penjadwalan, self-assessment (desk-evaluation) oleh program studi, visitasi, tindakan koreksi, dan pelaporan.
\end{abstract}

Kata kunci - Audit mutu internal, sistem informasi, sistem penjaminan mutu internal, system development life cycle, Universitas.

\section{Pendahuluan}

Berdasarkan Kebijakan Nasional Sistem Penjaminan Mutu Internal yaitu Undang-Undang No. 12 Tahun 2012 Tentang Pendidikan Tinggi [1] dan Permenristekdikti 62 Tahun 2016 Tentang Sistem Penjaminan Mutu Pendidikan Tinggi) [2] maka dijelaskan bahwa Sistem Penjaminan Mutu (SPM) Dikti terdiri dari komponen Standar Pendidikan Tinggi (Standar Dikti) yang terdiri dari Sistem Penjaminan Mutu Internal (SPMI) dan Sistem Penjaminan Mutu Eksternal (SPME).
SPMI dikasanakan dengan siklus yaitu Penetapan, Pelaksanaan, Evaluasi, Pengendalian, dan Peningkatan Standar Dikti atau disingkat P-P-E-P-P. Sementara SPME terdiri dari siklus Evaluasi data dan informasi; Penetapan status akreditasi dan peringkat terakreditasi; dan Pemantauan dan evaluasi status akreditasi dan peringkat terakreditasi, yang kemudian disingkat E-P-P. Kemudian kedua aktivitas dalam siklus tersebut menjadi masukan dan luaran pada komponen Pangkalan Data Pendidikan Tinggi (PD Dikti). Selanjutnya, seluruh komponen tersebut bersinergi dengan tujuan menghasilkan atau menciptakan budaya mutu [3].

SPMI merupakan kegiatan sistemik penjaminan mutu pendidikan tinggi oleh setiap perguruan tinggi secara otonom atau mandiri untuk mengendalikan dan meningkatkan mutu penyelenggaraan Pendidikan tinggi secara berencana dan berkelanjutan [4]. Seperti telah dijelaskan sebelumnya bahwa SPMI terdiri dari siklus P-P-E-P-P, dimana Audit Mutu Internal (AMI) merupakan aktivitas dalam siklus Pelaksanaan Standar Dikti. Aktivitas AMI yaitu melakukan pemeriksaan tentang pemenuhan Standar Dikti pada tahap pelaksanaan standar Dikti atau ketika standar Dikti tersebut dilaksanakan. Sesuai dengan International Standards for the Professional Practice of Internal Auditing bahwa audit internal adalah sebuah kegiatan yang mengakomodir konsultasi dan jaminan yang bersifat independen dan obyektif, dimana dirancang untuk menambah nilai dan meningkatkan operasi organisasi, dengan tujuan melakukan evaluasi dan perbaikan efektivitas manajemen resiko, pengendalian dan tata kelola yang dapat diimplementasikan secara sistematis dan disiplin [5].

Pelaksanaan AMI di perguruan tinggi tentu saja secara umum perlu merujuk pada kebijakan Nasional SPMI. Selain itu pelaksanaannya secara operasional dan spesifik perlu juga diatur oleh perguruan tinggi masing-masing, termasuk Universitas Tanjungpura (Untan) [6]. Pelaksanaan AMI di Untan pada beberapa tahun sebelumnya masih dilakukan secara manual baik saat audit dokumen maupun audit lapangan/visitasi. Pelaksanaan secara manual ini mengalami beberapa kendala terutama terkait pelaksanaan, pendokumentasian, dan kontrol AMI, misal sulitnya 
megetahui dengan cepat informasi terkait perbaikan mutu untuk setiap prodi secara periodik. Ditambah lagi kegiatan AMI yang idealnya dilaksanakan setiap tahun untuk setiap program studi, dan jumlah auditor yang terbatas. Sehubungan dengan hal tersebut, Untan melalui Pusat Penjaminan Mutu (PPM) mengembangakan sistem informasi pengelolaan AMI berbasis komputer, dimana audit dokumen maupun audit lapangan dilakukan dengan menggunakan aplikasi AMI yang dibangun berbasis web. Sistem informasi ini dikembangkan oleh Untan guna meningkatkan efisiensi pelaksanaan AMI di lingkungan Untan. Kondisi lain yang menuntut Untan terus meningkatkan efisiensi pelaksanaan AMI adalah jumlah Program Studi (Prodi) yang dimiliki Untan saat ini adalah 96 Prodi, dimana pelaksanaan AMI di Untan dijadwalkan setiap tahun. Sementara jumlah Auditor yang masih terbatas, maka untuk mengakomodir kebutuhan tersebut, sebuah sistem informasi diperlukan agar pelaksanaan AMI berjalan lebih efisien.

Sistem informasi AMI dirancang dengan pendekatan System Development Life Cycle (SDLC), yang terdiri dari beberapa tahapan, yaitu perencanaan, analisis, peracangan dan implementasi [7]. Penelitian terkait sistem informasi dan audit mutu juga telah menarik perhatian banyak peneliti antara lain [8] yang menjelaskan bahwa sistem informasi sebaiknya diterapkan untuk mengintegrasikan sistem penjaminan mutu demi meningkatkan keberhasilan dan menghasilkan informasi yang dapat diakses. Sementara [9] juga mendeskripsikan bahwa sistem informasi dapat membantu mengontrol proses bisnis yang berdampak pada peningkatan pengendalian internal dan dapat memberikan solusi terkait pelaksanaan audit. Secara umum rancangan sistem informasi AMI dapat digunakan untuk semua kebutuhan AMI perguruan tinggi, namun secara khusus sistem informasi AMI ini dirancang guna kepentingan Untan dalam mengimplementasikan siklus evaluasi pelaksanaan standar Dikti.

\section{TINJAUAN LITERATUR}

Pada bagian ini dipaparkan tinjauan secara literatur topik yang diangkat pada penelitian ini, terdapat dua konsep besar yang diangkat, yaitu AMI dan Pengembangan sistem informasi.

\section{A. Audit Mutu Internal (AMI)}

Audit Internal adalah proses tinjauan yang dilakukan kepada sebuah lembaga ataupun program, dimana fokus tinjauannya pada akuntabilitas, dan menentukan apakah maksud dan tujuan yang dinyatakan telah terpenuhi [10].

Pelaksanaan audit internal harus memperhatikan beberapa faktor berikut (1) independen, obyektif, terencana secara sistemik, dan berdasarkan serangkaian bukti; (2) mengandung unsur konsultasi yang bertujuan memberikan nilai tambah atau perbaikan bagi unit yang diaudit; (3) dilakukan oleh peer group terhadap unit atau institusi dan/atau program atau kegiatan, dengan memeriksa atau menginvestigasi prosedur, proses atau mekanisme [3].

Siklus pelaksaan AMI dirumuskan terdiri dari sepuluh tahapan (Gambar 1) mulai dari penetapan tujuan hingga pengkajian ulang yang perlu dilakukan oleh manajemen [11].

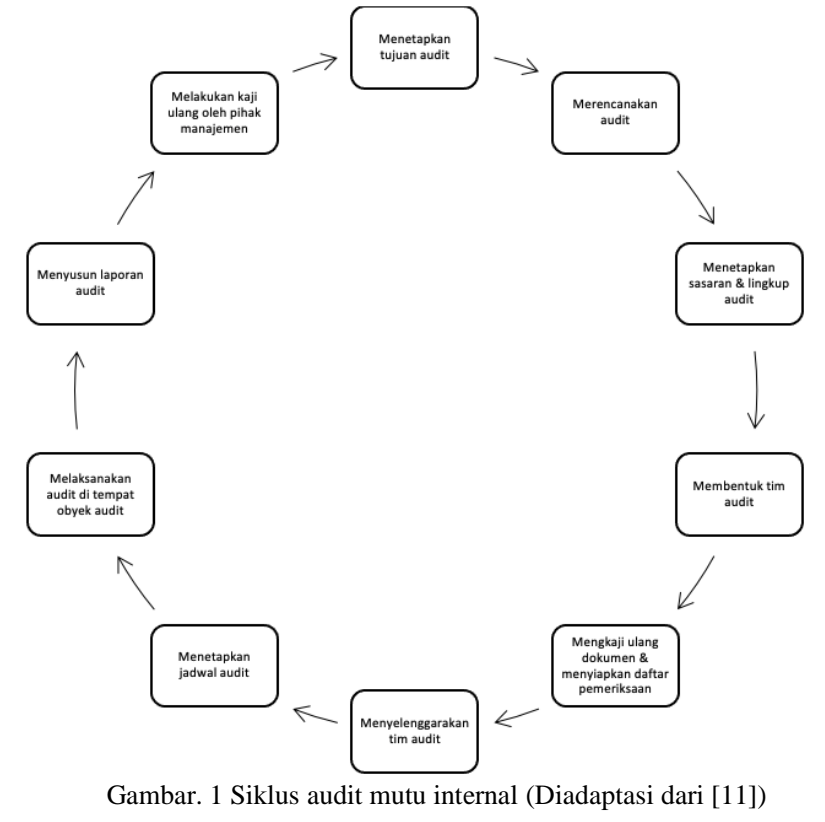

\section{B. Pengembangan Sistem Informasi}

Sistem informasi definisikan sebagai kumpulan komponenkomponen atau elemen-elemen yang saling terintegrasi untuk suatu tujuan tertentu. Kegiatan yang dilakukan pada pencapaian suatu tujuan tersebut adalah pengumpulan, pemprosesan, penyimpan, dan pendistribusian informasi. Informasi yang dihasilkan tersebut kemudian dapat dimanfaatkan untuk pengambilan keputusan, koordinasi, dan kontrol [12]-[15]. Pengembangan sistem informasi dilakukan dengan pendekatan SDLC, SDLC berperan sebagai metodologi untuk kebutuhan pegembangan sebuah sistem. Proses menterjemahkan setiap tahapan dalam SDLC di visualisasikan dengan menggunakan instrumen analisis dan peracangan. Instrumen tersebut ialah Object Oriented Analysis and Design (OOAD) yang merupakan sebuah cara untuk melakukan analisis dan peracangan dengan pendekatan berbasis objek. Pada OOAD dapat dijelaskan bahwa seluruh sistem yang sedang ditelaah adalah sebuah objek. Sementara alat untuk memvisualisasikan hasil analisis dan perancangan akan mengunakan Unified Modeling Language (UML). UML adalah sebuah standar bahasa grafis untuk menspesifikan, memvisualisasikan, merancang, dan mendokumentasikan artifact dari sebuah sistem [16], [17].

\section{Metodologi PENELITIAN}

Bagian ini menjelaskan bagaimana penelitian ini dibangun. Beberapa tahap dan pendekatan diambil untuk menjelaskan proses detail penyelesaian penelitian. Bagian pertama menjelaskan lingkup dari penelitian ini. Sementara bagian kedua menjelaskan langkah dan pendekatan yang dilakukan dalam membangun penelitian.

\section{A. Konteks Penelitian}

Fokus utama penelitian ini adalah tentang proses pelaksanaan audit mutu internal. Secara umum sistem yang dibangun dapat digunakan untuk semua kegiatan AMI yang 
merujuk pada kebijakan Nasional SPMI. Namun secara spesifik, sistem informasi AMI yang dibangun pada penelitian ini merujuk pada kebijakan, keadaan, dan kebutuhan Untan. Sistem AMI yang dikembangkan menggunakan pendekatan sistem informasi. Sistem informasi AMI Untan ini, tidak bersifat final, dan mengalami perbaikan dan perkembagan sesuai dengan kebutuhan organisasi.

\section{B. Program Penelitan}

Penelitian bertujuan merancang sebuah sistem informasi pengelolaan audit mutu internal (AMI) yang menjadi bagian dari siklus Sistem Penjaminan Mutu Internal (SPMI) pendidikan tinggi, yaitu evaluasi pelaksanaan standar Dikti. Guna memenuhi tujuan tersebut, dirancang empat sasaran penelitian, sebagai berikut:

1. Identifikasi parameter dari proses AMI

2. Analisis kebutuhan sistem informasi AMI

3. Deskripsi rancangan sistem AMI

4. Validasi Sistem AMI Untan

Guna memperjelas gambaran pelaksanaan penelitian, maka diilustrasikan kegiatan tersebut dalam Gambar 2.

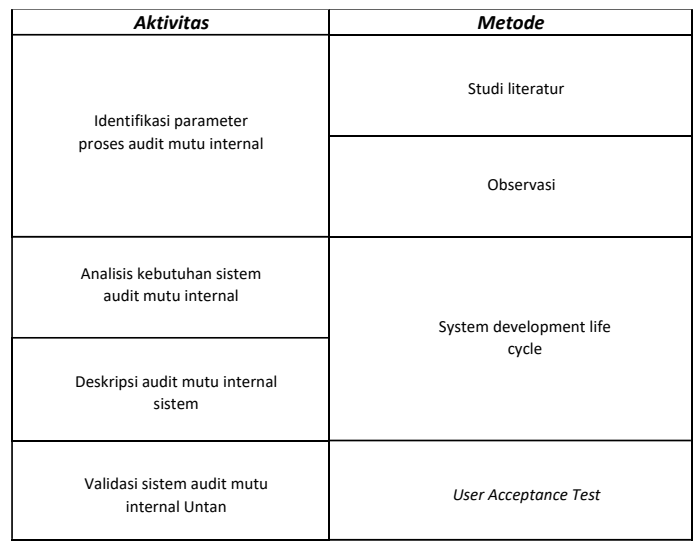

Gambar. 2 Program Penyelesaian Penelitian

Pada Gambar 2 tersebut, dijelaskan bahwa terdapat empat aktivitas yaitu Identifikasi parameter proses audit mutu internal; Analisis kebutuhan sistem dan Deskripsi sistem AMI; Validasi sistem AMI Untan. Masing-masing aktivitas tersebut dijelaskan sebagai berikut:

1) Identifikasi parameter dari proses AMI: Sistem AMI seperti yang telah dijelaskan memiliki mekanisme dan aturannya tersendiri, untuk dapat menggambarkan sebuah sistem dengan baik maka diperlukan sebuah deskripsi yang jelas dan komprehensif. Proses ilustrasi sistem dari sistem sebenarnya menggunakan beberapa instrumen pengembangan sistem. Tahap awal proses penggambaran tersebut yaitu dengan mengidentifikasi parameter-parameter terkait AMI. Proses identifikasi dilakukan dengan pendekatan literatur dan observasi. Proses identifikasi dengan pendekatan literature review dapat dilihat pada Bagian II, dimana ditemukan tahapan atau siklus SPMI dan AMI, serta aturan - aturan lain yang melingkupinya. Kajian tersebut mengandung kata kunci yang merupakan parameter utama yang menggambarkan sistem AMI, misalnya desk evaluation, daftar tilik, visitasi, observasi, tindakan koreksi, permintaan tindakan koreksi, temuan audit, auditor, dan auditee. Sementara pendekatan dengan observasi, dilakukan melalui pengamatan praktik AMI yang memang sudah dilakukan sejak sistem penjaminan mutu diterapkan di Untan. Secara umum parameter tersebut diatas sesuai dengan praktik yang selama ini dilakukan sesuai dengan kebijakan SPMI Untan [6].

2) Analisis kebutuhan sistem pengelolaan AMI: Penelitian ini menggunakan pendekatan SDLC. Proses Analisis dilakukan berdasarkan data yang telah dikumpulkan pada tahap sebelumnya. Analisis dideskripsikan selain dengan narasi juga menggunakan diagram, agar dapat terlihat keterhubungan satu objek dengan objek lainnya, sehingga proses analisis dapat dilakukan dengan mudah dan tepat sesuai dengan kebutuhan dan tujuan awal. Implementasi OOAD telah mulai diimplementasikan pada tahap ini, dimana identifikasi dilakukan berdasarkan objek - objek (bukan proses) yang terlibat dalam sistem, misalnya objek auditor, auditee, daftar tilik, dan laporan. Meskipun Objek - objek tersebut didapat dari proses yang coba digambarkan dengan berbagai diagram, namun prinsip object-oriented telah dimulai dari ranah berfikir pada sistem. Secara lengkap proses analisis dijelaskan pada Bagian IV di Sub Bagian Analisis kebutuhan AMI.

3) Deskripsi rancangan sistem AMI: Berdasarkan diagram yang diilustrasikan pada tahap Analisis (Gambar 3), kemudian rancangan sistem divisualisasikan dengan menggunakan class dan use case diagram. Class diagram berfungsi menggabarkan relasi antar objek yang terlibat dan bagaimana objek-objek tersebut di operasikan. Sementara Use case diagram, berfungsi untuk menjelaskan pola interaksi antara user dengan sistem. Selanjutnya rancangan tersebut diimplementasikan dalam bentuk aplikasi.

4) Validasi AMI Untan: Sebelum sistem diimplementasikan secara luas, tahapan yang dilakukan adalah menguji kelayakan sistem AMI. Pengujian ini menggunakan pendekatan User Acceptance Test (UAT), dimana mengukur pemahaman dari sisi pengguna. Pengujian dilakukan kepada PPM, auditor dan ketua program studi (auditee), dimana testing ini mengukur tingkat kemudahan pengunaan aplikasi dan keguanaan dalam aplikasi ini pada kegiatan AMI.

\section{HASIL PENELITIAN}

Bagian ini menjelaskan analisis dan hasil penelitian dimana untuk mempermudah pemahaman, maka pemaparan dilakukan berdasarkan tahapan-tahapan dalam SDLC.

\section{A. Perencanaan Sistem Informasi AMI}

Berdasarkan keterangan yang didapat dari Pusat Penjamainan Mutu (PPM) Untan, bahwa pelaksanaan AMI di Untan telah dilaksankan sejak lama, dimana pelaksanaan tersebut mengadopsi kebijakan Nasional yang berlaku. Dalam prakteknya, ditemukan beberapa tantangan terkait proses pelaksanaan AMI, misalnya jumlah prodi yang cukup banyak, dengan jumlah auditor yang terbatas; dokumentasi pelaksanaan yang masih belum terkendali, yang 
mengakibatkan kontrol, tindak lanjut, dan perbaikan menjadi kurang efisien. Upaya peningkatan efisiensi terus dilakukan terutama dalam pelaksanaan AMI. Sebuah sistem informasi diperlukan dalam mendukung serta menjawab beberapa tantangan yang dihadapi Untan. Salah satu luaran dari Sistem informasi tersebut adalah dibuatnya aplikasi AMI Untan berbasis web, yang memfasilitasi semua aktor yang terlibat dalam business process AMI seperti auditor, auditee (Ketua Program Studi), dan PPM. Seluruh proses detail sistem AMI merujuk pada mekanisme AMI yang berlaku (Kebijakan Nasional SPMI dan Kebijakan SPMI Untan).

\section{B. Analisis kebutuhan sistem AMI}

Berdasarkan perencanaan yang telah disampaikan sebelumnya, bahwa sistem AMI melibatkan pengguna yaitu (1) PPM, berperan sebagai fasilitator pelaksanaan AMI di Untan. Peran yang dilakukan oleh PPM mulai dari proses penjadwalan kegiatan regular AMI, hingga kegiatan AMI yang juga dapat dilaksanakan karena kebutuhan atau permintaan dari program studi. Selanjutnya, PPM juga menyiapkan daftar tilik secara umum, namun apa saja yang menjadi fokus terkait daftar tilik diseleksi oleh auditor masing-masing, daftar tilik ini adalah pertanyaan- pertanyaan yang akan diajukan selama proses audit. PPM juga berhak membuat prioritas-prioritas pertanyaan dalam satu siklus evaluasi, misalnya fokus pada standar Pendidikan, penelitian, ataupun standar lainnya. (2) Auditor, adalah seseorang yang telah mengikuti pelatihan dan lulus ujian sebagai auditor internal yang diselenggarakan di Untan, atau institusi yang relevan. Auditor nantinya akan melakukan pengecekan jawaban desk evaluation yang telah diisi sebelumnya oleh auditee (program studi), kemudian auditor melakukan cross check jawaban dari auditee dengan melakukan visitasi. (3) Auditee (Program Studi), di Untan yang menjadi auditee adalah ketua program studi atau yang mewakili. Auditee, perlu melengkapi pertanyaan pada daftar tilik, dan kemudian mengirimkan jawabannya ke PPM, yang kemudian oleh PPM diteruskan ke Auditor yang bertugas pada Prodi tersebut.

Selanjutnya terkait proses yang dilakukan pada praktek AMI di Untan, seperti yang dijelaskan mengadopsi kebijakan Nasional dan institusi, dimana proses tersebut meliputi proses penjadwalan pelaksanaan AMI, desk evaluation, penambahan daftar tilik, visitasi, Tindakan koreksi, dokumentasi dan pelaporan hasil. Dari proses dan pengguna yang terlibat didalam sistem AMI kemudian dihubungkan sedemikian rupa sehingga membentuk sebuah sistem yang sesuai dengan tujuan awal AMI, yaitu meningkatkan efisiensi pelaksanaan AMI di Untan. Pada sistem ini masing-masing pengguna berperan pada sisinya masing-masing, dan setiap proses saling terkait satu dengan lainnya sesuai dengan siklus pelaksanaan AMI, hingga proses pengendalian dan evaluasi berjalan sesuai dengan yang ditargetkan. Identifikasi pengguna, proses, dan relasi antar proses adalah satu tahapan untuk mempertegas kebutuhan sistem AMI. Ilustrasi komponen pengguna, proses, dan relasi kemudian dituangkan dalam sebuah diagram (Gambar 3).

Pada Gambar 3 dijelaskan bagaimana interaksi entitas entitas yang terlibat dalam proses pelaksanaan AMI yaitu
PPM selaku penanggung jawab kegiatan, Auditor selaku pelaksana kegiatan audit, dan auditee selaku pihak yang di audit. Masing-masing entitas ini kemudian direlasikan berdasarkan tugas dan fungsi masing-masing. Pada Gambar tersebut juga dijelaskan luaran yang dihasilkan oleh masingmasing entitas.

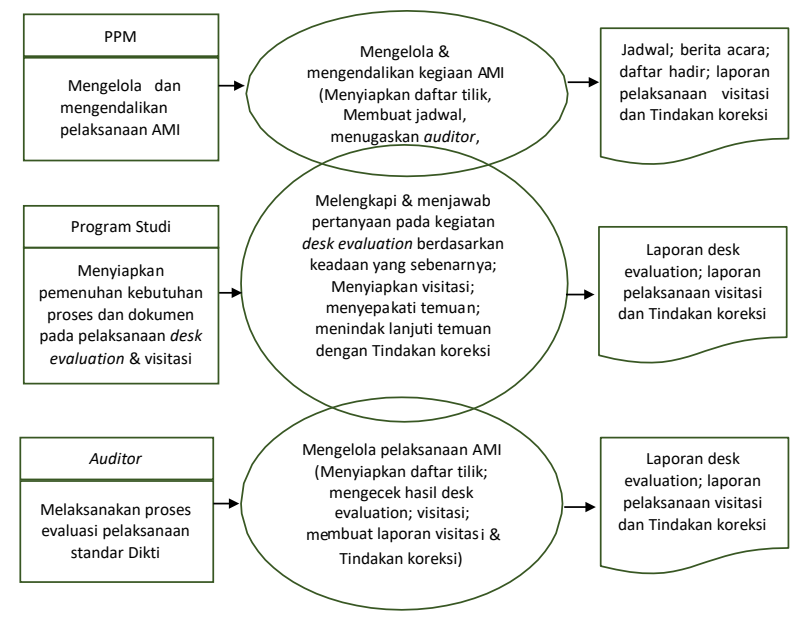

Gambar. 3 Gambaran umum proses AMI Untan

\section{Deskripsi Rancangan Sistem AMI}

Berdasarkan analisis yang menggambarkan komponenkomponen yang terlibat dengan sistem AMI yang divisualisasikan dalam bentuk diagram, kemudian diagram tersebut diterjemahkan dengan menggunakan instrumen UML, yaitu dituangkan dalam bentuk class diagram. Diagram ini bertujuan untuk menggambarkan apa saja objek dan bagaimana objek tersebut saling terkait satu dengan lainnya. Objek - objek tadi direpresentasikan dalam bentuk class (Gambar 4). Setiap class terdapat tiga komponen, lapisan pertama menjelaskan nama objek, lapisan kedua adalah atribut-atribut yang melekat pada objek, dan lapisan ketiga adalah operation, atau method yang dapat digunakan oleh masing-masing objek tersebut.

Selanjutnya setelah objek-objek yang terlibat menjadi jelas dengan Bahasa standar pada UML, kemudian saatnya, dibangun bagaimana pola interaksi antara user dengan aplikasi yang dibangun. Penjelasan interaksi tersebut menggunakan use case diagram (Gambar 5). Pada gambar tersebut terlihat ada tiga aktor yang terlibat yaitu (PPM, Auditor, dan Auditee). Masing-masing aktor tersebut memiliki pola interaksinya masing-masing yang secara visual dapat terlihat pada Gambar 5. PPM memilki pola interaksi mulai dari pengelolaan pengguna, jadwal, pelaksanaan AMI, proses dokumentasi, dan pelaporan; Auditor memiliki pola interaksi melakukan pengecekan desk evaluation, visitasi, dokumentasi, dan Tindakan koreksi; Auditee, dalam hal ini dilakukan oleh seorang ketua program studi, memiliki pola interaksi yaitu terlibat dalam pelaksanaan desk evaluation, visitasi, dokumentasi, dan Tindakan koreksi. 

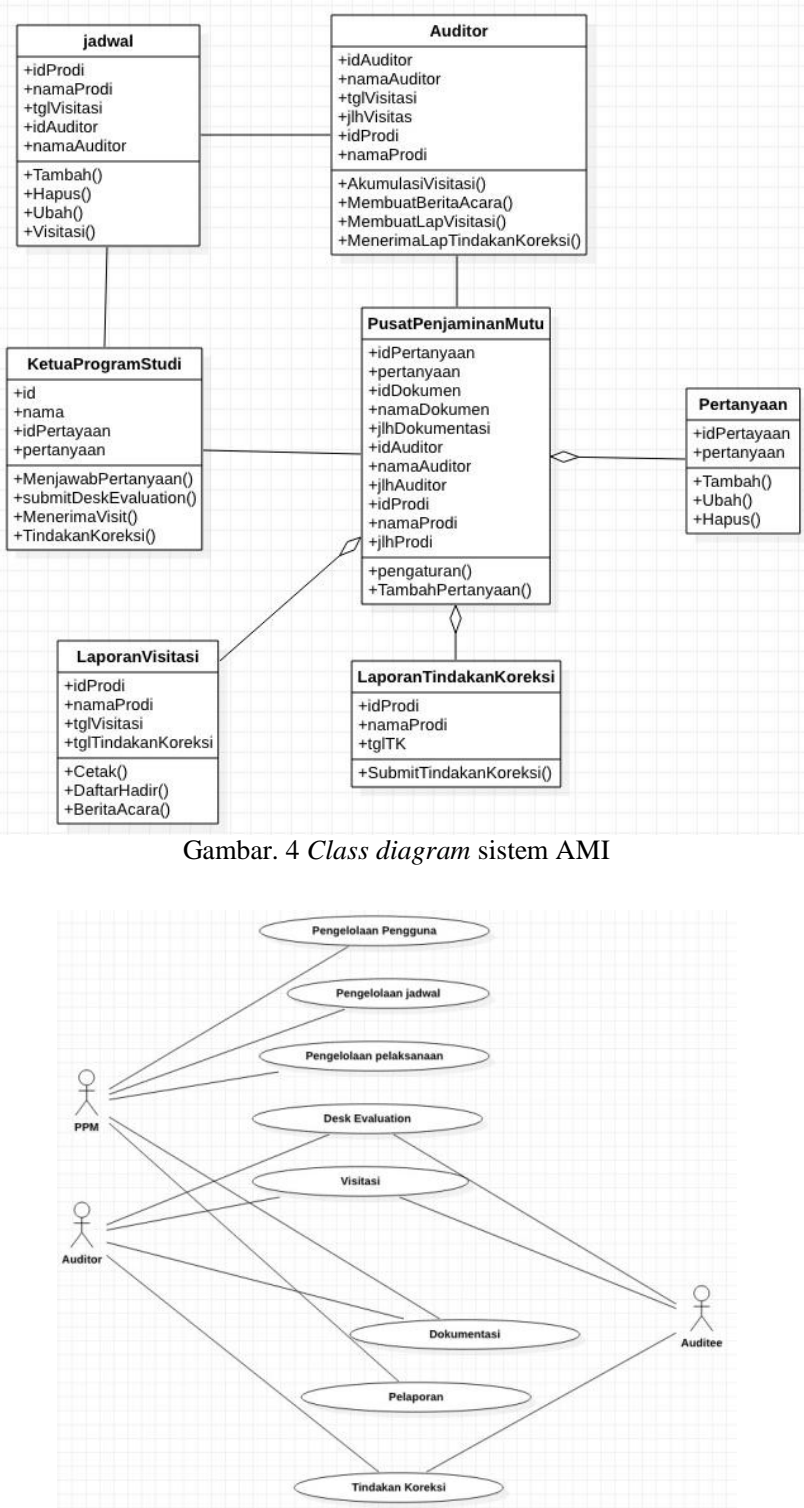

Gambar. 5 Use Case Diagram sistem AMI

Berdasarkan rancangan di atas, kemudian dibangun Aplikasi AMI berbasis web yang digunakan untuk pelaksanaan AMI itu sendiri. Aplikasi ini mengakomodir tiga peran pengguna yaitu Admin (PPM); Auditor; dan Program Studi. Masing-masing peran dapan login ke akunnya dengan username dan password yang telah diberikan atau dikelola oleh PPM (Gambar 6). Jika sudah berhasil login maka akan muncul halaman seperti pada Gambar 7, dimana terdapat menu Dashboard, Pengaturan, dan Logout.

Pada Gambar 7 di menu dashboard, terdapat informasi tahun pelaksanaan, daftar program studi, tanggal desk evaluation, tanggal visitasi, tanggal koreksi dilakukan. Tentu saja tanggal dan daftar tersebut akan terisi setalah semua dilengkapi pada menu pengaturan.

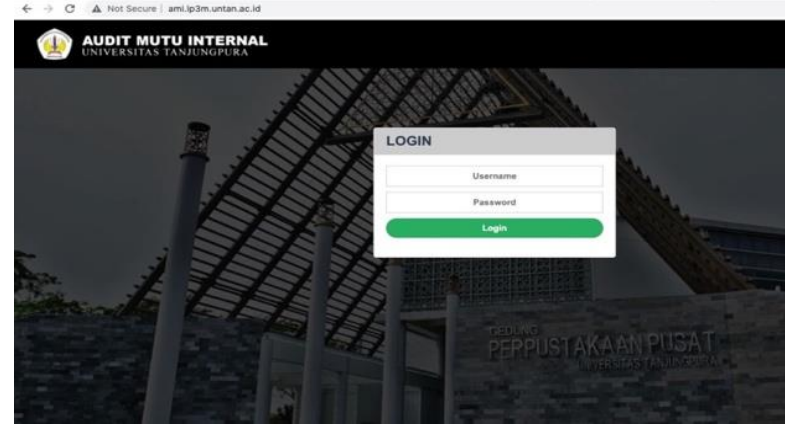

Gambar. 6 Halaman Login

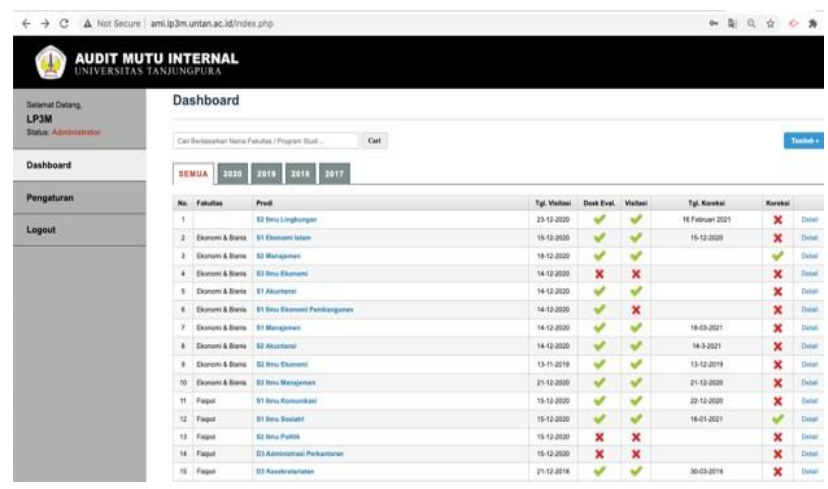

Gambar. 7 Tampilan dasboard aplikasi AMI

Admin juga mengatur jadwal dan memilih auditor yang ditugaskan, beserta pemberian daftar tilik yang akan diajukan, daftar tilik ini dapat dipilih sesuai dengan fokus AMI pada setiap periodenya. Daftar tilik ini juga bersifat dinamis, sehingga bisa ditambahkan atau dihilangkan (Gambar 8).

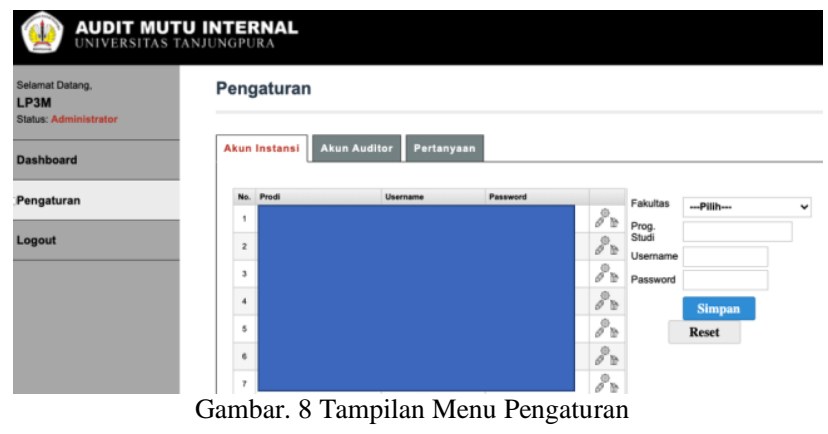

Sementara kegiatan setelah melakukan kegiatan visitasi, auditor diminta melengkapi beberapa isian sebagai laporan, kemudian, laporan ini sebelum dikirim, harus mendapat persetujuan atau diinformasikan terlebih dahulu dari Auditee (Prodi) (Gambar 9).

Kemudian setelah visitasi dilakukan Tindakan koreksi dapat dilakukan oleh Auditee (Prodi), selanjutnya dikirim ke Auditor. Setelah semua kegiatan selesai, maka laporan Tindakan koreksinya dapat dicetak seperti berikut (Gambar 10). 

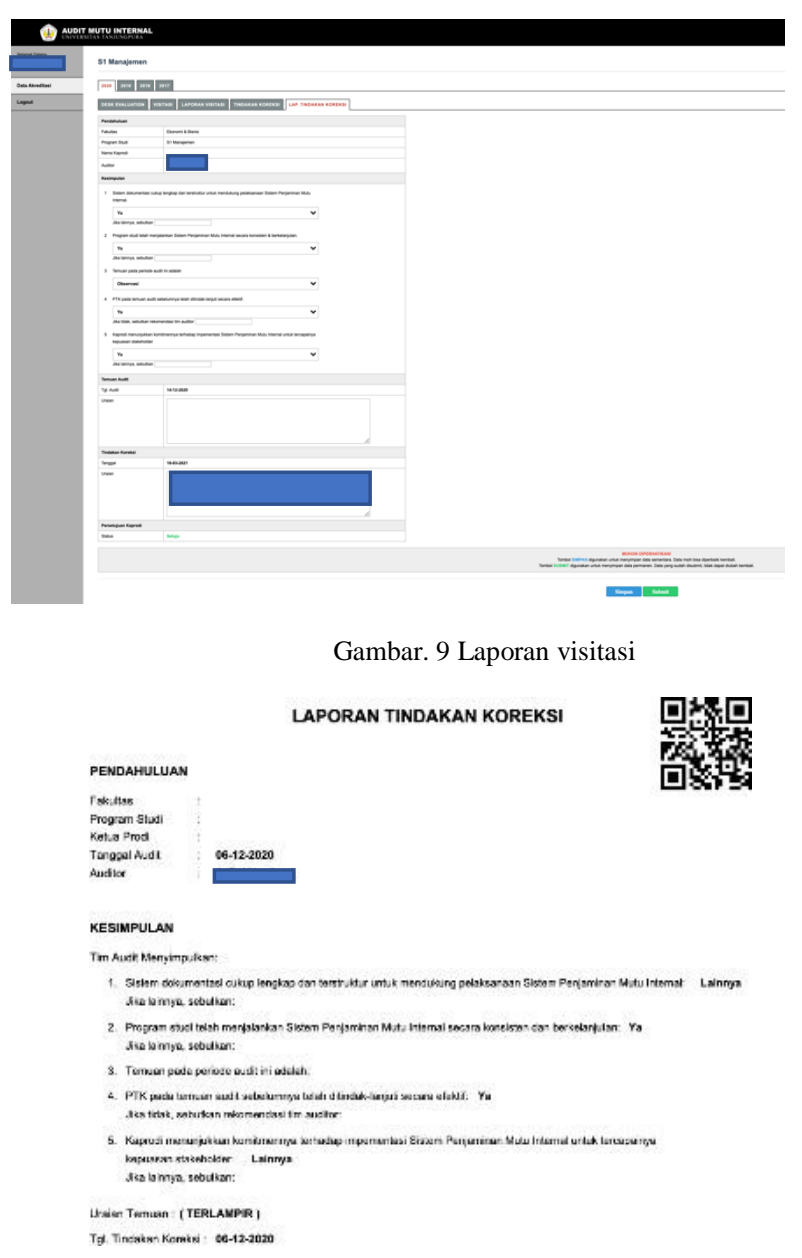

Gambar. 10 Hasil cetakan laporan tindakan koreksi

\section{Validasi Sistem Informasi AMI}

Tahapan yang harus dilakukan sebelum sistem informasi AMI digunakan adalah pengujian sistem. Tahapan ini dilakukan untuk mengetahui sejauh mana kelayakan sistem. Sistem AMI Untan di uji dengan pendekatan UAT, dengan metode Focus Group Discussion (FGD). FGD adalah sebuah pendekatan untuk mengukur kecenderungan yang ada pada individu terkait persepsi suatu fokus penelitian [18]. FGD juga [19] dapat berlaku sebagai cara pengumpulan data; sebagai alat untuk meyakinkan peneliti terhadap informasi yang telah dimiliki dari metode yang lain.

Pada testing pertama, dilakukan dengan FGD, dimana melibatkan pengembang sistem dan Tim PPM Untan (diwakili 4 orang responden dan 1 orang pengembang). Kegiatan $F G D$ ini beragendakan percobaan terhadap aplikasi yang telah dibangun dengan pemahaman AMI yang ada di Untan. FGD yang dilakukan mengukur, tingkat kemudahan dan kegunaan dari aplikasi yang dibangun. Dari kegiatan ini dihasilkan masukan terkait, daftar tilik yang awalnya dibuat secara statis; Validasi kegiatan visitasi, dimana awalnya seorang Kaprodi tidak melalui fase persetujuan terhadap hasil visitasi; Tindakan koreksi juga masih memerlukan perbaikan, karena di aplikasi proses perbaikan dilakukan di luar sistem. Satu masukkan penting juga disampaiakan terkait adalah keterlibatan manajemen dalam pemantauan dan pengendalaian pelaksanaan kegiatan AMI ini. Namun, mengingat kebutuhan sistem informasi AMI yang mendesak untuk diimplementasikan, maka Tim PPM juga menyampaikan bahwa, aplikasi AMI dapat digunakan terlebih dahulu, kedepannya dapat dilakukan perbaikan dari waktu ke waktu. Secara umum, aplikasi dapat digunakan secara mudah dan berfungsi sesuai dengan aturan AMI yang ada, namun beberapa penambahan fitur masih diperlukan seperti yang telah dijelaskan sebelumnya.

Pengujian tahap kedua dilakukan dengan melibatkan auditor dan ketua progam studi, dengan pengukuran kriteria yang sama dengan FGD sebelumnya. Kegiatan ini dilaksanakan pada tanggal 2 dan 3 Desember 2020. Kegiatan ini menghasilkan, bahwa auditor meyampaikan masukan secara teknis seperti perlu adanya rumusan penilaian secara kuantitatif terhadap hasil audit, sehingga dapat memudahkan auditor dalam mengambil kesimpulan hasil visitasi, dan halhal teknis seperti permintaan auto-saving terhadap hasil-hasil temuan di lapangan (pada saat visitasi). Sementara, untuk Auditee atau Ketua Program Studi dalam hal ini, tidak memberikan banyak masukkan. Hal ini dapat dipahami karena, sisi Ketua Prodi sifatnya melengkapi isian atau daftar tilik yang dijawab sesuai dengan kondisi Prodinya masingmasing. Dari kedua kegiatan tersebut dapat disimpulkan bahwa aplikasi dapat dan mudah digunakan dan telah menggambarkan business process kegiatan Audit Mutu Internal, namun masih perlu dilakukan penambahan beberapa fasilitas, yang berguna untuk meningkatkan efisiensi pelaksanaan AMI.

\section{KESIMPULAN}

Sistem informasi AMI dibangun berdasarkan aturan dan kebijakan Nasional yang berlaku, ditambah aturan dan pedoman pelaksanaan SPMI yang dimiliki Untan. Secara umum rancangan ini tentunya juga dapat diadopsi oleh semua kebutuhan sistem informasi audit mutu internal di pergurua tinggi, namun tentu saja perlu penyesuaian-penyesuaian terkait aturan yang bersifat institusional. Aplikasi AMI Untan yang dibangun tidak bersifat final, maksudnya diproyeksikan untuk dikembangakan sesuai dengan masukan yang diberikan pengguna.

Sistem Informasi AMI ini dikembangkan dengan pedekatan SDLC, dimana setiap tahapannya adalah berupa siklus yang mejadi masukan atas siklus atau tahapan berikutnya. Ini sesuai dengan perencanaan pengembangan aplikasi yang berlangsung terbuka atas perbaikan dan pengembangan. Proses analisis dan perancangan dilakukan dengan pendekatan OOAD, dimana sistem dipandang dan terdiri dari objek-objek. Instrumen yang digunakan untuk melaksanakan dan menggambarkan analisis dan desain adalah dengan UML, dimana diagram yang digunakan adalah class diagram dan use case diagram.

Sistem ini kemudian diuji ke pengguna yaitu PPM selaku pengelola sistem ini, kemudian Auditor dan Auditee (Program Studi), dengan melaksanakan FGD. Pengujian dilakukan untuk menggumpulkan masukan sehingga diketahui persepsi pengguna terkait tingkat kemudahan dan kegunaan dari sistem 
AMI yang akan digunakan. Secara umum bahwa aplikasi AMI ini dapat digunakan dengan mudah dan susuai kebutuhan proses AMI. Terdapat masukan penting untuk pengembangan aplikasi kedepannya, yang diberikan oleh tim PPM yaitu terkait keterlibatan pihak manajemen dalam pelaksanaan dan pengendalian kegiatan AMI ini.

\section{UCAPAN TERIMA KASIH}

Penulis mengucapkan terimakasih kepada Rektor dan Ketua Lembaga Pengembangan Pembelajaran dan Penjaminan Mutu Untan yang telah memfasilitasi dalam perancangan sistem informasi pengelolaan AMI. Ucapan yang sama juga penulis sampaikan kepada tim Pusat Penjaminan Mutu (PPM), Auditor Untan, dan Tim Pengembang sistem informasi AMI Untan yang telah memberikan masukan dalam pengembangan sistem ini.

\section{REFERENSI}

[1] Pemerintah Indonesia. (2012). Undang-Undang No. 12. Tahun 2012 Tentang Pendidikan Tinggi. Jakarta: Sekretariat Negara.

[2] Kementerian Riset, Teknologi, dan Teknologi. (2016). Permenristekdikti 62 Tahun 2016 Tentang Sistem Penjaminan Mutu Pendidikan Tinggi.

[3] Direktorat Penjaminan Mutu. (2019) Kebijakan Nasional Sistem Penjaminan Mutu Internal. Kementerian Riset, Teknologi, dan Pendidikan Tinggi.

[4] Direktorat Penjaminan Mutu, 2018. Pedoman Sistem Penjaminan Mutu Internal, Kementerian Riset, Teknologi, dan Pendidikan Tinggi, Jakarta

[5] NCA Self-Study Committee. (2014). International Standards for the Professional Practice of Internal Auditing.

[6] Pusat Penjaminan Mutu, Untan. (2018) Kebijakan SPMI Universitas Tanjungpura. PPM Untan, Pontianak.

[7] Tegarden, D. P., Dennis, A., \& Wixom, B. H. (2012). Systems analysis and design with UML. John Wiley \& Sons, Inc.

[8] Kahveci, T. C., Uygun, Ö., Yurtsever, U., \& Ilyas, S. (2012). Quality assurance in higher education institutions using strategic information systems. Procedia-Social and behavioral sciences, 55 (2012), 161-167.

[9] Nusa, I.B. (2020). Quality of audit system information for internal control effectiveness. In International Conference on Business, Economic, Social Science, and Humanities-Economics, Business and Management Track, 198-202. Atlantis Press.

[10] Vlăsceanu, L., Grünberg, L., \& Pârlea, D. (2004). Quality assurance and accreditation: A glossary of basic terms and definitions (p. 25). Bucharest: Unesco-Cepes.

[11] Kantor Penjaminan Mutu ITS. (2020) Panduan Pelaksanaan Audit Mutu Internal SPMI ITS. Institut Teknologi Sepuluh Nopember, Surabaya.

[12] Nickerson, R. C. (2000) Business and Information Systems, Addison Wesley (2nd Ed)

[13] Date, C. J. (2003) An Introduction to Database Systems, Addison Wesley (8th Ed).

[14] Kendall, K. \& Kendall, J. E. (2013) Systems Analysis \& Design, Prentice-Hall (9th Ed).

[15] Ripanti,E. F. (2020) Pengembangan Model Evaluasi pada Integrated Information Systems di Universitas: Systematic Literature Review. Jurnal Edukasi dan Penelitian Informatika, 6(2), 224 - 235.

[16] Booch, G., Jacobson, I. \& Rumbauh, J. (2005) Unified Modeling Language User Guide. 2nd Ed, Addison-Wesley Professional.

[17] Booch, G., Maksimchuk, R., Engle, M., Young, B., Conallen, J. \& Houston, K. (2007) Object-Oriented Analysis and Design with Applications. Pearson Education, Inc.

[18] Hoed, B.H. (1995) Diskusi Kelompok Terfokus, Fakultas Sastra Universitas Indonesia, Jakarta.

[19] Koentjoro, N. (2005) Metode-Metode Penelitian Masyarakat. Jakarta: PT Gramedia Pustaka Utama. 